\title{
アルカリシリカ反応生成物の染色と顕微鏡観察
}

\section{MICROSCOPIC OBSERVATION OF THE PRODUCTS OF THE ALKALI-SILICA REACTION IN THE DYED THIN SECTIONS OF CONCRETE CORES}

\author{
西 山 孝* 日下部吉彦**
}

By Takashi NISHIYAMA and Yoshihiko KUSAKABE

\begin{abstract}
Dyeing the products of the alkali-aggregate reaction made it possible to distinguish them from the components of the concrete under a microscopy. Cyanoacrylate mixed with a coloring substance was used to dye the alkali-silica gel red.

Cyanoacrylate reacts readily with water contained in gel but not with the components of the concrete. Examination of dyed thin sections revealed a few concrete cores with expansion of alkali-silica reactive aggregates. This method appears to be useful for observing the alkali-aggregate reaction.
\end{abstract}

Keywords: alkari-aggregate reaction, dyed thin section, microscopic observation, cyanoacrylate

\section{1.はじめに}

アルカリ骨材反応に起因するコンクリート構造物のひ びわれ損傷が近年しばしば観察報告されている.アルカ リ骨材反応には，アルカリシリカ反応，アルカリ炭酸塩 岩反応およびアルカリシリケート反応の 3 つの夕イプが あるといわれているが，これまでにわが国で発見された 反応例のほとんどはアルカリシリカ反応である.このア ルカリシリカ反応は骨材から溶出したシリカとコンク リート中のアルカリが反応し, まずアルカリシリカゲル が形成され,このゲルが吸水膨張するために, コンクリー トが損傷すると考えられている(1) 6).

アルカリシリカ反応の機構やコンクリート劣化の状況 を的確に把握するためには，まず反応生成物の規模, 形 状などを知ることが重要である。ひびわれ損傷が大きい 場合には肉眼による観察が可能であるが, 多数発生して いる小さなひびわれの形状やごく少量のアルカリシリカ 反応生成物については顕微鏡観察によらざるを得 ず7) 10), しかもこの観察は必ずしも容易とはいいがたい. その主な理由はアルカリシリカ反応生成物が無色の非晶

\footnotetext{
* 正会員 工博 京都大学講師 工学部資源工学科 ( 勈 京都市左京区吉田本町)

** 工博 京都大学教授 工学部資源工学科 (同上)
}

質物質であり，通常の薄片による顕微鏡観察では，その 光学的性質から生成物を判定することが難しいからであ る.

そこで，アルカリシリカ反応生成物を着色させること によって,顕微鏡下で容易に観察できる方法を検討した. 染色の方法としてはシラン系接着剤に赤色の色素を加え たものを使用し，アルカリシリカ反応生成物を着色させ るとともにクラックや空陌を赤色の接着剤で充填させ た.

\section{2. 試料の作成}

\section{（1）染色剤の選定}

アルカリシリカ反応を喚起したコンクリートにはすで に多数のクラックが発生し, 破壊が進んでいるので9), 染色にあたっては次のような条件を考慮した.すなわち (1)アルカリシリカ反応生成物には着色するが造岩鉱物そ の他とは反応しないもの, (2)強い接着力をもっているこ と, (3)クラックや空隙に沿って深く浸透する材料である こと, (4)容易に色素を溶かしこむことである. 近年，さ まざまな目的に対応した種々の接着剤が開発されている が, そのなかで粘性度が低く, 親水性に富んだ接着剤と してシアノアクリレートがあり，この接着剤が最も上記 の条件に適合していると判断された. シアノアクリレー 
ト（市販品名，アロンアルファ，シアノボンドなど）は 一般に被着材表面のわずかな水分と反応し，瞬間的に固 結するもので，アルカリシリカ反応生成物のように多量 の水分をもったゲルとは容易に反応するが，造岩鉱物や セメントなどとは反応しにくい，また粘性が低く，割れ 目にもよく浸透する．しかしながら市販のシアノアクリ レートは無色透明であるためそのままでは使用できず， これに染料の添加を試みた。着色剂としては赤と青およ び不透明な白の三種の色素を選び観察した結果, 赤色が 最も効果的であることが明らかになった。

\section{(2) 薄片の作成}

岩石の構成物を顕微鏡で調べるのに薄片が用いられて いる．これはスライドグラスに貼りつけた岩石片を研磨 し，0.02 0.03mm の厚さにまで薄くしたもので, 偏光 顕微鏡によって造岩鉱物の光学的な種々の性質が観察測 定できるようになる．通常行われている薄片作製手順を 以下のように変更して, アルカリシリカ反応生成物やク ラックおよび空隙の着色を試みた。 (1)試料を切断し，切 断面をホットプレート $\left(\right.$ 約 $\left.80^{\circ} \mathrm{C}\right)$ 上で 30 分間乾燥させ, シアノアクリレートを塗布し，クラックやアルカリ骨材 反応生成物に赤色のシアノアクリレートをしみこませ る. (2)切断面を研磨し，スライドグラスに貼りつける. (3)貼りつけた試料片を $0.1 \mathrm{~mm}$ 程度に切断し, 切断面に 再度赤色のシアノアクリレートを塗布し, 注意樑く研磨 する. (4)所定の厚さにまで研磨し仕上げる（図一1）.

\section{3. 観 察 例}

アルカリ骨材反応によって劣化したコンクリート片お よびモルタルバー試験法により膨張の認められた試験片 をすでに述べたような方法により染色し，顕微鏡観察し た。 その結果，アルカリシリカ反応生成物は(1)反応性骨 材中に形成されているもの，(2)骨材とモルタルとの境界 あるいはモルタル中のクラックを充填しているもの, (3) モルタル中に存在し，球形をなすものとに分けられ，そ れぞれの形状は写真一1, 2, 3に示すとおりで，赤く着 色している部分が，シアノアクリレートが浸透したとこ ろである.

\section{（1）骨材中のアルカリシリカ反応生成物}

安山岩やチャートの骨材中にはしばしばクラックを充 填したアルカリシリカ反応生成物が観察される．いずれ の骨材においてもクラックの方向は不規則で，チャート では部分的にクラックの幅の変化が著しく，アルカリシ リカ反応生成物がアメーバ状に形成されているところも 存在する（写真一 $1 \mathrm{~B}, \mathrm{C}, \mathrm{D})$. 安山岩では，クラック幅 の変化は比較的少なく，モルタルを切って別の骨材へク ラックが生長しているようなところも観察される（写真 -1A）。また，花崗岩骨材によるアルカリシリカ反応の 報告は数少ないが, 写真一 $1 \mathrm{E}, \mathrm{F}$ に示す花崗岩では, 石英中にアルカリシリカ反応生成物が認められ，周辺部 が漸移していることからこの石英はアルカリシリカ反応 に関与していたものと推察される.この試料はチャート, 泥質岩とともに花崗岩が骨材として使われ，ひびわれを 起こしたコンクリート構造物から採取されたものであ る.

（2）骨材とモルタルとの境界あるいはモルタル中の クラックを充媜しているアルカリシリカ反応生 成物

アルカリシリカ反応生成物は反応性骨材の周辺部およ びモルタル中のクラックに最も多くみられ，反応性物質 としては安山岩，チャート，石英砂なぼがある．写真一 $2 \mathrm{E}$ ではアルカリシリカ反応生成物はクラックが石英粒 と接するところで急激に増加している、また，石英粒と モルタルとの境界を拡大すると，境界は鮮明ではなく， 漸移しているのがみられる（写真一2D）。このことは, 石英からシリカの溶脱があったことを示唆している.

（3）モルタル中の球状のアルカリシリカ反応生成物

モルタル中には球状の特異なアルカリ骨材反応生成物

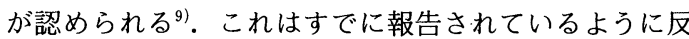
応性骨材の位置で生成されたアルカリシリカゲルが移動 しコンクリート気泡中に溜ったもの ${ }^{1)}$ と考えられるが, 球の周辺あるいは内部にはアルカリシリカ反応に関連し てできた微細な鉱物が排列している。また，この球には 反応生成物の膨張により起こったと思われるクラックお よび反応生成物が固結収縮したときにできたと考えられ

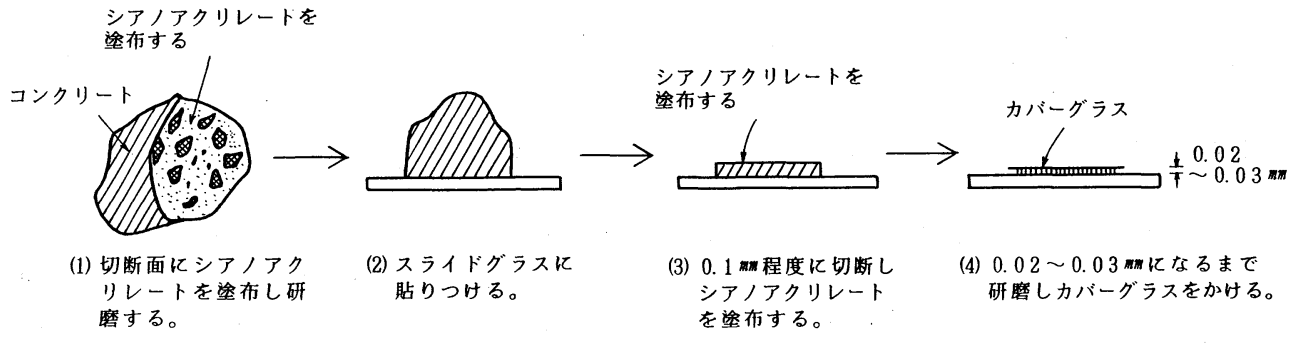

図一1シアノアクリレートにより着色させたコンクリート薄片の作製手頑 

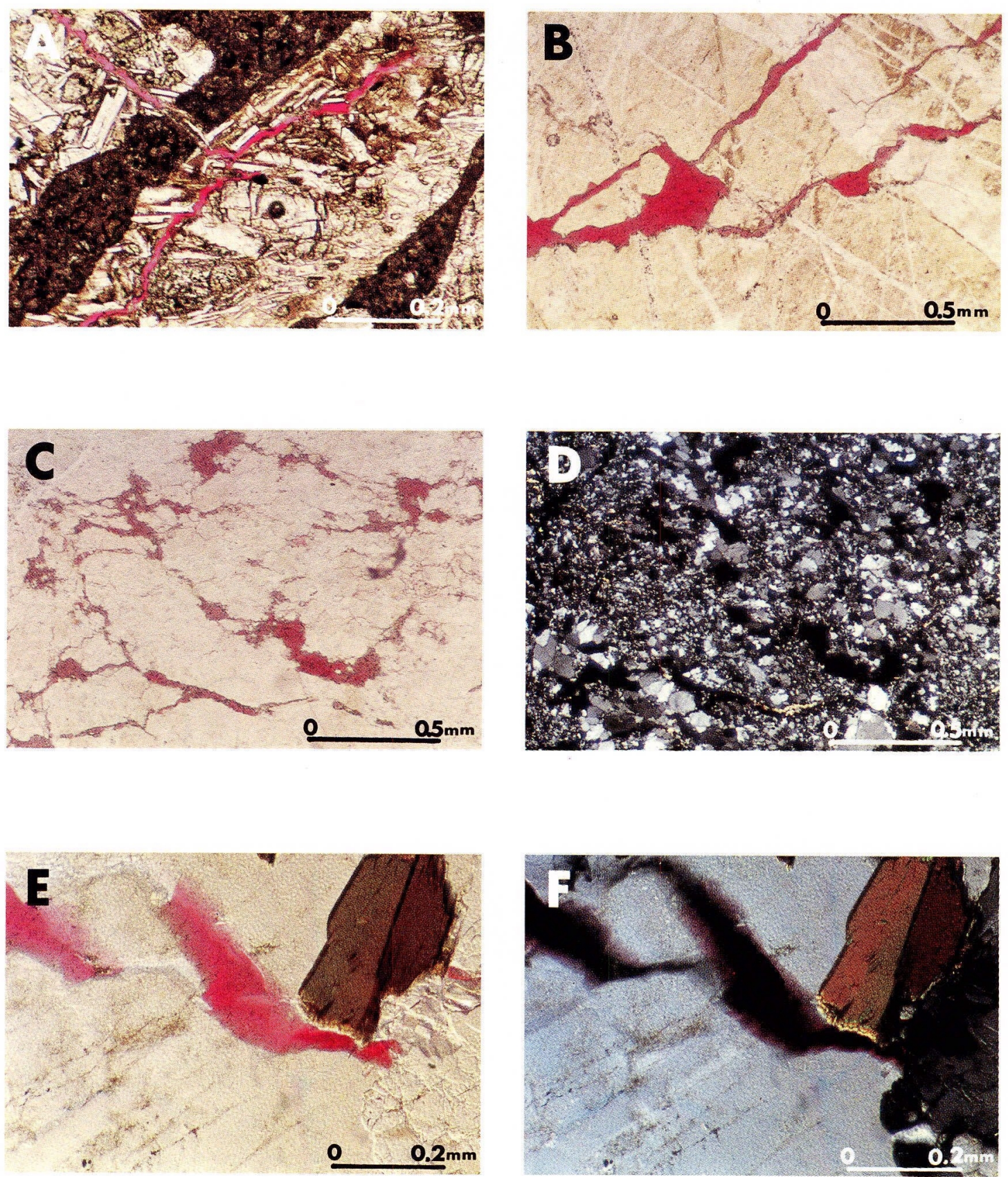

写真一1＼cjkstart骨材中のアルカリシリカ反応生成物

A：安山岩中に形成されたクラックとクラックを充媜したアルカリシリカ反応生成物. 骨材周辺には反応縁は認められない (単ニコル, モルタルバー 試料 MA-1)

B , C , D : チャート中の不規則な形をしたアルカリシリカ反応生成物. 石英粒子の大きさ, 紐脈に関係なく反応は進んでいる（B; 単ニコル，劣化構 造物試料 CA-3，C; 単ニコル，劣化構造物試料 CA-3，D；Cをクロスニコルで観察したもの).

$\mathrm{E}, \mathrm{F}$ : 花崗岩中の石英に形成されたアルカリシリカ反応生成物. 生成物と石英との境界が漸移していることから,この石英粒子からシリカの溶脱が 起こったものと推測される（ $\mathrm{E}$; 単ニコル，劣化構造物試料 CA-1, F; Eをクロスニコルで観察したもの)。 

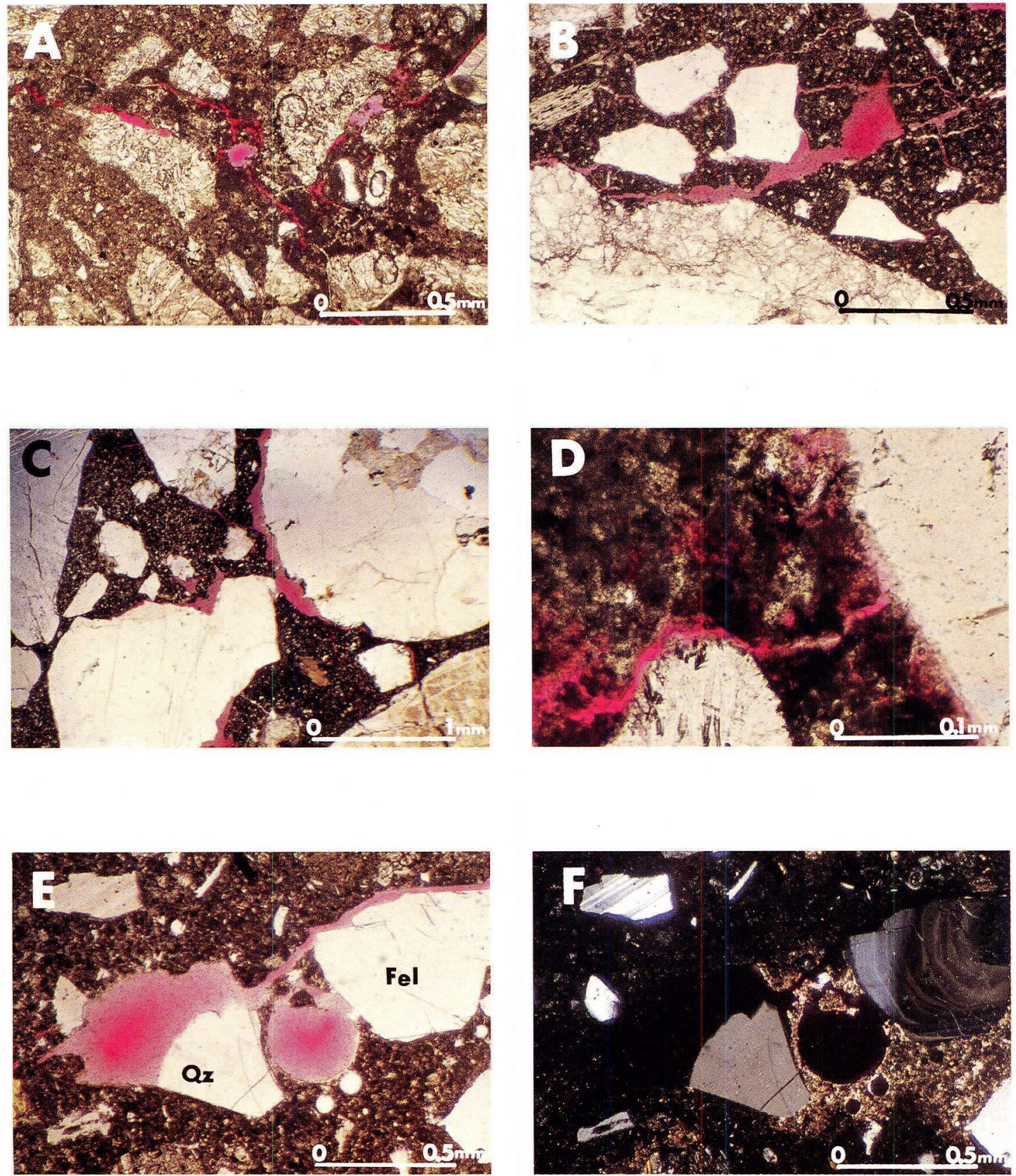

写真一2＼cjkstart骨材とモルタルの境界あるいはモルタル中のクラックを充填しているアルカリシリカ反応生成物

\footnotetext{
A， B ：モルタル中およびモルタルと骨材の境界部に形成された不規則なアルカリシリカ反応生成物. 反応性骨材は A が安山岩，Bがチャートと石英 砂であるが, 骨材中にはアルカリシリカ反応生成物は認められない ( A ; 単ニコル, モルタルバー試料 MA-1, B ; 単二コル, 劣化構造物試料 CA-3)

C , D : 石英の周辺部に形成されたアルカリシリカ反応生成物. D は高倍率で観察したもので，石英の周辺部ではシリカの溶脱が起こっているものと 推察される ( C; 単ニコル, 劣化構造物試料 CA-3, D ; 単ニコル, 劣化構造物試料 CA-3).

$\mathrm{E}, \mathrm{F}$ : 石英片 $(\mathrm{Qz})$ および長石片 (Fel) とモルタルとの境界部に形成されたアルカリ骨材反応生成物で, 石英片のところで生成物は膨大している（E ;単ニコル，劣化構造物試料 C-4,F;Eをクロスニコルで観察したもの).
} 

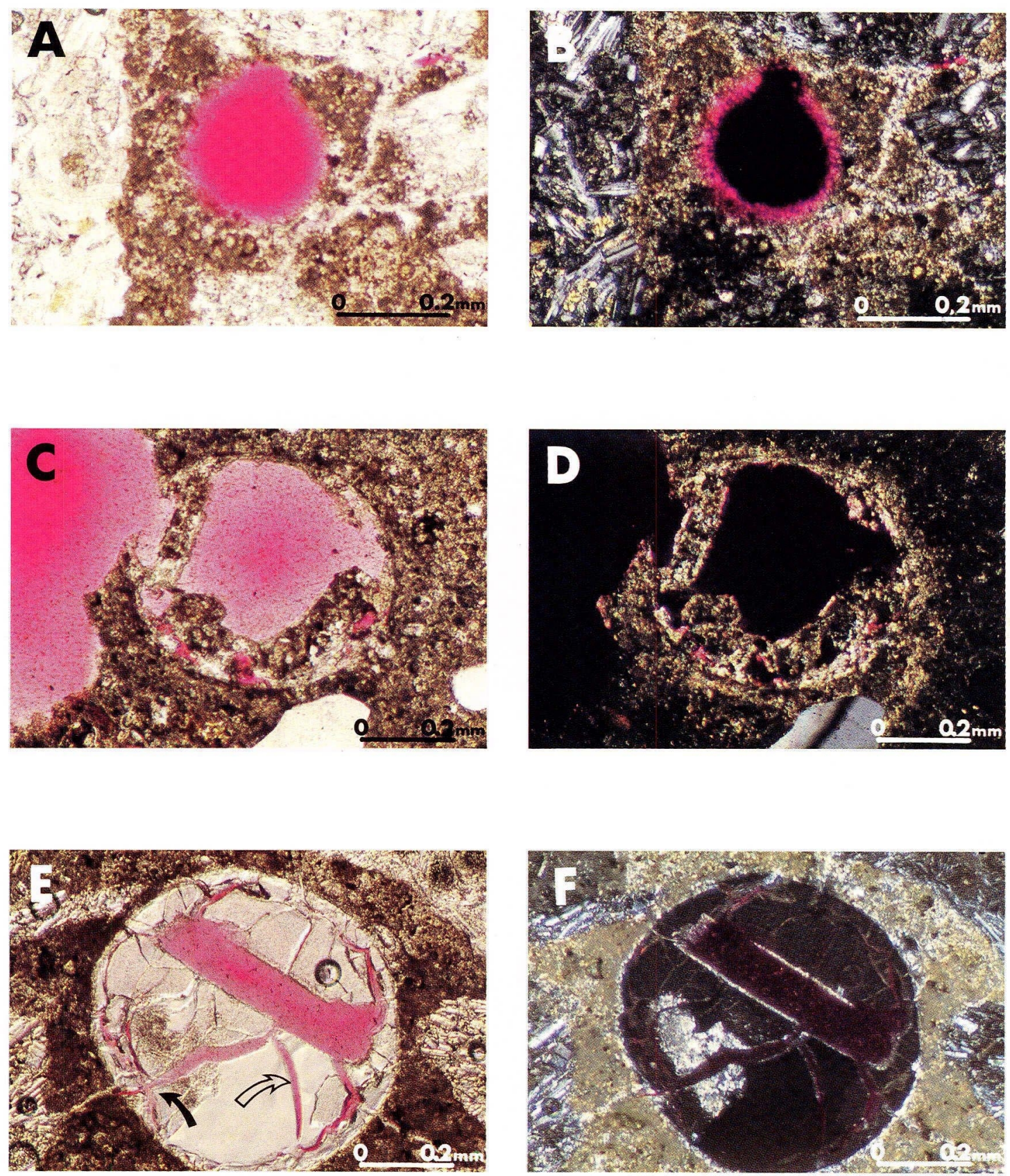

写真一3モルタル中の球形をしたアルカリシリカ反応生成物

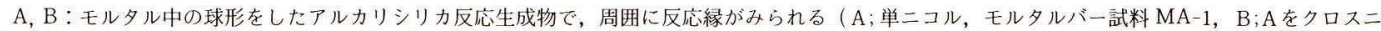
コルで観察したもの).

C, D : モルタル中に球形の反応縁がみられ，そのなかの一部を反応生成物が充たしている（A；単ニコル，劣化構造物試料 C-4, D;Cをクロスニコ ルで観察したもの).

$\mathrm{E}, \mathrm{F}$ ：モルタル中の球形をしたアルカリシリカ反応生成物で，ゲルが固結するときに收縮してできた内部のひびわれ（ら）と膨張時にできたと思わ れる外部のひびわれ（の）が観察される（E；単ニコル，モルタルバー試料 MA-1, F;Eをクロスニコルで観察したもの). 
るクラックがしばしば観察される（写真一 $3 \mathrm{C}, \mathrm{D}, \mathrm{E}$, F)。なお，一般にモルタル中には気泡が存在し，この 気泡がシアノアクリレートで充填されると前者と同様の 形態を示すが，アルカリ骨材反応による球形物にはその 周辺に特徵的な鉱物の集合体がみられるのに対して気泡 の場合にはシアノアクリレートが固結する際に収縮して できた空間が認められることによって両者の区別ができ る.

\section{4.おわりに}

シアノアクリレートを用いて，アルカリシリカ反応生 成物を赤色に着色し，顕微鏡観察する方法を検討した。 その結果, シアノアクリレートはアルカリシリカ反応生 成物によく浸透し，赤色にするため，骨材およびモル夕 ルからアルカリシリカ反応物あるいは反応生成物により 起因したクラックを容易に区別できることが判明した。 これらはアルカリシリカ反応の機構やコンクリート構造 物劣化の進展状況の把握などに有効に利用できると思わ れる.

本研究を行うにあたって, 大阪セメント株式会社研究 所 中野錦一博士には試料の提供をいただいた。また， 東亜合成化学工業株式会社には接着剤について, 日本地 科学社 北川元紀氏には薄片作製についていろいろご協 カいただいた．ここに記して感謝の意を表する。
参 考 文 献

1）日本材料学会：アルカリ骨材反応に関するシンポジウム, pp. 1 171, 1985.

2）森野奎二：わが国のアルカリ骨材反応, 骨材資源, No. 60, pp. 184 193, 1984.

3）川村満紀・枷場重正：アルカリ・シリカ反応のメカニズ ム, コンクリート工学, Vol.22, No. 2, pp.6〜33, 1984 年 2 月.

4）福島正人・二村誠二：コンクリート用砕石のアルカリ骨 材反応性, セメント・コンクリート, No. 438, 1983 年 8 月.

5）西 晴哉・水上国男・今井友宏・江藤清光：安山岩のア ルカリ骨材反応, セメント・コンクリート, No. 435, 1983 年 5 月.

6) 有泉 昌：コンクリート用骨材の問題点, 粘土科学, Vol. 19, No. 2, pp. $41 \sim 55,1979$ 年.

7) Dolar-Mantuani L. : Handbook of Concrete Aggregates a Petrographic and Technological Evaluation, pp. 79 125, Noyes Publications, 1983.

8) Gillott, J.E. : Alkali-reactivity Problems with Emphasis on Canadian Aggregates, Eng. Geol., Vol.23, pp. $29 \sim 43,1986$.

9) Idorn, G. M. : Durability of Concrete Structures in Denmark, Thesis of Doctor of Science, pp. 82 169, 1967.

10) Gogte, B. S. : An Evaluation of Common Indian Rocks with Special Reference to Alkali-aggregate Reactions, Eng. Geol., Vol. 7, pp. 135 153, 1973.

(1987.3.9 • 受付) 